ELORE (ISSN 1456-3010), vol. 16 - 2/2009.

Julkaisija: Suomen Kansantietouden Tutkijain Seura ry.

[http://www.elore.fi/arkisto/2_09/art_tapaninen_2_09.pdf]

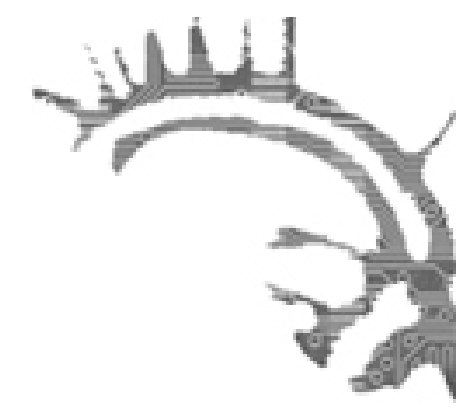

\title{
SINNE JA TAKAISIN: LÄHIÖKENTTÄTYÖSTÄ KAUPUNKIETNOGRAFIAAN
}

\section{$\underline{\text { Anna-Maria Tapaninen }}$}

\section{ETNOGRAFISOINTIA}

Kuvittele saapuneesi yhtäkkiä sinne, kentälle, eurooppalaisen suurkaupungin kupeella sijaitsevaan lähiöön, yhden perheen keittiöön, yhdessä kolmen muun noviisin kanssa. Tutkimusta ohjaavat kuitenkin taustalla, ainakin potentiaalisena tukena, häämöttävät etnografisen tutkimuksen perinteet. Eikä siinä kaikki. Kenttää on eri tavoin kirjallisesti kuvattu noin kahden vuosituhannen ajan. Yksi Euroopan vanhimmista yliopistoista on vain parinkymmenen kilometrin päässä. Napolin yliopistossa niin antropologinen, sosiologinen kuin historiallinenkin tutkimus on kohdistunut enimmäkseen juuri lähialueille. Tutkijan äidinkieltä suomea opiskellaan siellä Italian sïrtomaahaaveita varten perustetussa "orientaalisessa instituutissa". Tällaiset olivat kenttätyöni lähtökohdat Pozzuolin kaupungissa Napolin metropoliksen alueella lokakuussa 1985. Tässä esseessä tarkastelen sitä, miten etnografin työ tarkoittaa yhtäältä tiedon karttumisen odottamattomia muotoja kenttätyössä ja toisaalta jatkuvasti uudelleen kehkeytyvää suhdetta kentän, kenttätyön ja etnografisen kuvauksen välillä.(1)

Johdatus mukailee Bronislaw Malinowskin (1961 [1922], 4) kuuluisaa saapumiskertomusta: "Imagine yourself suddenly set down surrounded by all your gear, alone on a tropical beach close to a native village, while the launch or dinghy which has brought you sails away out of sight. " Kömpelö rinnastus kohdistaa huomion siihen, miten etnografisen tutkimuksen olosuhteet ovat vuosikymmenten varrella muuttuneet. Etnografit eivät enää katso kartoittavansa ennen tuntemattomia alueita, kuvaavansa "alkuasukkaiden mentaliteettia", tarjoavansa "totuudenmukaisia kuvia heimoelämästä" tai tekevänsä kenttätyötä etäällä "valkoisista miehistä", niin kuin Malinowski tieteellistä menetelmäänsä kuvasi. Voidaan kuitenkin ajatella, että Malinowski puhui aikansa käsitteillä ja retoriikalla asioista, jotka edelleen kuvaavat kenttätyön ideaa. Kenttätyö edellyttää yhä osallistuvaa havainnointia, kielen taitamista, paikalleen asettumista, 


\section{AnNa-Maria TAPANinen}

avoimuutta erilaisille, monesti formuloimattomille tiedon muodoille ja tutkittavien ihmisten näkökulmien tavoittelemista. Vaikka "etnografin magia" (Malinowski 1961, 6) näyttäytyi Malinowskilla ennen kaikkea tieteellisenä kenttätyömetodina, se viittasi myös aina relevanttiin kysymykseen kenttätyön ja etnografisen tiedon välisestä suhteesta (Stocking 1992, 59).

Etnografisoidun antropologian klassinen kausi kesti noin neljä vuosikymmentä, ja sen tunnusmerkkinä näyttää olleen, ainakin sitä seuranneen kriisin näkökulmasta, intensiivisen kenttätyön, monografian ja teoreettisen argumentoinnin suhteellisen ongelmaton yhteys (ks. Fardon 1990; Stocking 1992; Spencer 2001). 1960-luvulta lähtien etnografista taikuutta on tarkasteltu kriittisesti, vaikka lumouksen ei voi sanoa haihtuneen. Käsitteen etnografia molemmat osat ovat kyseenalaistuneet, niin kuvaukset kansoista kuin kansojen kuvattavuuskin (Siikala 1997). Kohteiden määrittäminen kulttuurin tai yhteiskunnan käsitteiden kautta selvärajaisiksi, sisäisesti yhtenäisiksi ja saarimaisiksi kokonaisuuksiksi, etnoksiksi, on käynyt mahdottomaksi. Etnografioiden poetiikan ja politiikan tarkastelussa (Clifford \& Marcus 1986) esitettiin, että magia saa voimansa tekstuaalisesta etäännyttämisestä. Kentän jäsentämisen, metodologian ja etnografisen kirjoittamisen ja teorian väliset yhteydet ovat edelleen, joskin uusilla, kritiikin ja metakritiikin purkamilla tavoilla kenties entistä keskeisempiä (ks. Faubion 2001; Spencer 2001). "Kun etnografian lokus menettää fokuksen, etnografin taikuuden hokkus-pokkuksen uskottavuus kyseenalaistuu" (Stocking 1992, 368).

Kuten Jean Comaroff on huomauttanut (1994, 4), etenkin yhdysvaltalaisten antropologien "luulotautisen" itsekritiikin seurauksena etnografiset tekemisen tavat vaikuttavat anakronistisilta kun taas relevantteina pidetyt kysymykset eivät näytä erityisesti antropologisilta. Tämä on johtanut koeteltujen menetelmien ja uusien, luonteeltaan globaalien ja abstraktien tutkimuskohteiden välisen kuilun syvenemiseen. Postmodernismin myötä maaperä etnografien alla on muuttunut epävakaaksi, ja Comaroff kysyykin, mihin etnografi voisi nyt pystyttää telttansa. Tämä kysymys on edelleen ajankohtainen, mutta yltiöpäisestä kritiikistä on siirrytty uudenlaiseen etnografian kukoistukseen, jossa kyseenalaistavista, refleksiivisistä otteista on tullut etnografian valtavirrassa osa rutiinia (esim. Fardon 1991; Spencer 2001; Metcalf 2003). Antropologisissa keskusteluissa etnografia ei ole vain menetelmä vaan se on jatkuvasti sidoksissa tieteenalan teoreettisiin peruskysymyksiin. Näin osallistuvan havainnoinnin katsominen muokkaantuu erityisiksi näkemisen tavoiksi (ks. Wolcott 1999).

\section{ETELÄÄN}

Etelä-Euroopan antropologisen tutkimuksen pioneerit ovat kuvanneet asettumistaan etnografisesti tuntemattomalle maaperälle varsin malinowskilaiseen tyyliin. Julian Pitt-Rivers $(1954, x v)$ kertoi olleensa varustautunut linjasukuja koskevilla teorioilla, mutta havainneensa Espanjan olevan toista maata kuin Afrikka ja joutuneensa "ajattelemaan asiat itse". Samoin John Campbell $(1992,151)$ kertoi ottaneensa 1950-luvulla mukaansa Kreikkaan "niin eriskummalliselta kuin se nyt vaikuttaakin" ainoastaan Evans-Pritchardin teoksen The Nuer. Yhtä lailla omituiselta voi tosin vaikuttaa tämä 
huomautus, Campbell kun tutki opettajansa lailla paimentolaisia. Toisaalle juurtunut antropologinen teoria sekä toisista lähtökohdista tehtävä Euroopan yhteiskuntatieteellinen ja historiallinen tutkimus avaavat etnografiselle tutkimukselle jännitteisiä kenttiä.

Kun etnografit etsiytyvät tapojensa mukaisesti reuna-alueille, käsitys erityisen, jopa erillisen, maailman olemassaolosta syntyy helposti. Lähikentillä, Euroopassa ja kaupungeissa, etnografinen ote voi olla juuri läheisen vuorovaikutuksen kautta, osallistuvan havainnoinnin seurauksena, loitontava. Etelä-Euroopan antropologista tutkimusta on syytetty tutkimuskohteiden välimerellistämisestä, eksotisoinnista ja tribalisoinnista. Etnografien menetelmällinen tee se itse -työkalupakki onkin sisältänyt vanhoja antropologisia välineitä. Kun "toista Eurooppaa" kuvataan sen reuna-alueiden fragmenttien kautta, puhuminen tutun tekemisestä vieraaksi on menettänyt viattomuutensa.

Malinowskin esiin manaamisessa artikkelin alussa ei ole vain mautonta ironiaa. Miten etäisen ja vieraan tutkimukseen kehitetty etnografisen tutkimuksen traditio voisi olla mielekäs suurkaupungin lähiössä kun jo Malinowski (1961, xv) ennusti etnografian tutkimuskohteen olevan katoamaisillaan? Niin sanotusta etnografiasta innostuneet sosiaalitieteilijät ja kulttuurintutkijat ovat loppujen lopuksi - tai kenties alun alkaenkin - erilaisen tutkimustehtävän edessä kuin antropologit kenttätöissään.

Konventionaalisen kenttätyön kenties illusorinen kuvajainen häämöttää uudenlaisten tutkimuskohteiden taustalla, muistuttaen ymmärryksen rajoista. Pienestä on tehty etnografisen tutkimuksen kautta teoreettisesti suurta mutta ylivoimaisen suurilta vaikuttavien tutkimuskohteiden keskellä etnografiaa voi määrittää paradoksaalisesti pienuus (ks. Tapaninen 1997). Riittämättömyydentunteen inspiroimana pohdin tässä kirjoituksessa kysymystä etnografisista strategioista. Nämä eivät ole metodisia teknisessä merkityksessä vaan koskevat etnografisen tiedon jäljittämisen tapoja ja luonnetta. Antropologian rajaseuduilla, esimerkiksi Euroopassa tai kaupungeissa, etnografinen tutkimus tekemisen tapana ja päämääränä johtaa sosiaalisen maailman rakentamiseen erityisellä tavalla kompleksisena, antropologian vertailevan perspektiivin kautta.

Etnografinen ote kattaa tutkimusprosessin kauttaaltaan. Tutkimus johtaa etnografiaan, kuvaukseen kansasta, eli etnografia on tutkimuksen päämäärä. Kenttätyö muovaa ja ennakoi kirjoittamisen tapoja, ei pelkästään kartuta yksittäisiä faktoja. Etnografia on edelleen metodologinen ote, jossa intensiivisen - ja "riittävän pitkän" - kenttätyön fyysinen läsnäolo yhdistyy etnografiseen kuvaukseen niin, että tutkimusprosessia ei voi pilkkoa erillisiin osiin. Pohdinkin etnografista orientaatiota tältä kannalta, tulkintojen kehkeytymistä kirjoittamisen ja kenttätyön välisenä liikkeenä, jossa etnografinen asennoituminen (ks. Ortner 1995), orientaatio tai mielikuvitus on ratkaisevaa määrättyjen menetelmien sijasta. Artikkelini ei ole kuitenkaan matkakertomus vaan kuvaan pikemminkin kertomuksen matkaa, toisin sanoen jäsennän kuvauksen kenttätyöstä lopusta käsin, etnografian kautta. (2)

\section{Paikantamisia}

Yhteyshenkilönämme toiminut Pozzuolin kunnan virkamies saattoi meidät (3) Rione Toianon lähiöön, josta hän oli onnistunut löytämään meille yhden, vain yhden, 


\section{Anna-Maria Tapaninen}

isäntäperheen ja huoneen. Ja sieltä löysimme itsemme, nähtävästi kentältä, rehellisesti sanoen tietämättä, minne olimme tupsahtaneet. Varsinainen tutkimuskysymyksemme, naisten arkielämän kulttuurinen rakentuminen eteläitalialaisessa kaupunkiyhteisössä, sai odottaa. Ensin oli selvitettävä maaperää.

"Missä" lienee etnografian ensimmäisiä kysymyksiä, seikka, joka selvitetään yleensä monografioiden alaotsikoissa ja oman nimen jälkeen toisia antropologeja tavatessa. Mutta samalla tätä kysymystä on pohdittava yhä uudelleen. Etnografinen kenttä rakentuu ainakin kolmella tasolla: 1) läsnäolon kautta, kenttätyön positioista ja yhteyksistä, 2) alueellisen tutkimustradition muodostamalle maaperälle sekä 3) etnografisena maisemana, jonka rakentumista ohjaavat jatkuvasti muuttuvat teoreettiset maisemat ja kirjoittamisen konventiot akateemisilla kentillä. Paikka kaikkein arkisimmassakin merkityksessään on hahmotettava itse, omin jaloin ja aistein sekä paikallisten opastuksella. Lähiön ominaislaatua yleensä luonnehtii se, että se ei ole paikka kuin suhteessa toisiin paikkoihin, näin myös kenttätyössä. Monet toianolaisista oli evakuoitu Pozzuolin vanhoista kortteleista, osa oli saanut lähiöasuntonsa asuntonsa ahtauden tai huonokuntoisuuden takia. Toianossa perheet olivat asuneet kenttätyöni alkaessa kymmenisen vuotta. Satunnaisella sisäänpääsylläni yhteen perheeseen oli kauaskantoisia seurauksia; tästä kiinnekohdasta käsin hahmotin ympäristöä. Mutta paikallistuntemuksen voi saavuttaa vain paikallisten avulla, antropologia on tosiaan "paikallista tietoa” (Geertz 1983). Niinpä fyysistä tilaa tai kenttää rakensivat, fragmentoivat ja tihensivät sosiaaliselle tilalle ominaiset moniulotteiset ja kiistanalaiset yhteydet. Näiden jäsentämisestä tulikin tutkimukseni keskeinen kysymys.

Toiseksi sijainti rakentuu jo ennen kenttätyön alkua suhteessa etnografian paikallistaviin, alueellisiin traditioihin (ks. Fardon 1990). Antropologisen Etelä-Italian ja Rione Toianon välille virinneet yhteydet olivat läsnä jo kenttätyössä. Pitt-Riversin ja Campbellin ajoista valinnan mahdollisuudet ovat laajentuneet. Kirjoja ei tarvitse eikä edes voi kantaa mukanaan sillä, kuinka ollakaan, paikalliset ovat kirjoittaneet jo kauan ennen antropologeja. Esimerkiksi "napolistiikka", Italian yhteiskuntatieteellinen tutkimus, Välimeren ja Etelä-Euroopan etnografia, Euroopan antropologinen tutkimus ja urbaani antropologia muodostavat usein keskenään yhteen sovittamattomia keskusteluja. Antropologian vertaileva perspektiivi tietysti ulottaa kysymykset tätä laajemmalle.

Paikan kuvaaminen etnografiassa on eri tavoin sidoksissa edellä mainittuihin paikallistamisen kokemuksellisiin ja diskursiivisiin tapoihin. Kenttätyön jälkeen monille varmaan valkeneekin se, kuinka klassisille monografioille tyypillinen objektivoiva kuvaustyyli on edellyttänyt kuvitteellista siirtymistä ulko- ja yläpuolelle. Kun konventionaalisesti ensimmäisen luvun otsikko saattoi olla "The Setting", on ilmeistä, että tämä ei ole pelkkää konkreettisten puitteiden kuvausta vaan - sanan muiden merkitysten mukaan - myös maisema, tausta, (näytelmän) lavastus tai tapahtumapaikka, toisin sanoen osa näyttämöllepanoa ja itse kertomusta. Paikallistamisen kolmas aspekti koskeekin etnografisen maailman tai maiseman tekstuaalista ja teoreettista luomista. Tätä tarkastelen artikkelin loppuosassa. 


\section{NAAPURIN ROUVIA}

Isäntäperheeni otti neljä ulkomaalaista kotiinsa rahan takia, mutta vähänpä he aavistivat seurauksista. Me emme suostuneet tähän mielettömältä tuntuvaan järjestelyyn, asumaan yhdessä, vaan etsimme välillä epätoivoisestikin muita perheitä. Lisäksi tingimme kohtuuttomana pitämästämme täysihoidon hinnasta. Pitkä selvittelyvaihe päättyi niin, että minä jäin yksin asumaan perheeseen, kohtuullisella korvauksella. Kiusallisten keskustelujen aikana tutustuimme toisiimme, kohteliaisuus ja varuillaanolo väistyivät. Monet asemani ongelmallisuuteen liittyvät kysymykset tulivat eksplikoiduiksi. Niin perheeni kuin sittemmin myös muut toianolaiset ovat pitäneet asemaani isäntäperheessäni etuoikeutettuna. Olin di casa, en siis täysin ulkopuolinen vaan omituinen perheenjäsen. Sittemmin, kun en saanut enää maksaa huolenpidosta, olen ollut kiitollisuudenvelan ja kiintymyksen sitoma vieraana, perheenjäsenenä ja ystävänä. Siksi tutkijan roolini on ollut kiusallinen. Isäntäperheessäni ei ole koskaan, ainakaan minun kuullessani, mainittu oudosta harrastuksestani muille. (4)

Aloin viettää yhä enemmän aikaa perheen keittiössä, missä opin vähitellen tavoille ja opin italiaa omaksumalla paikallisen puhetavan sanastoa ja idiomeja. Tunsin jatkuvasti olevani hölmö ja hidas. Isäntäperheeni sai minut uskomaan, että erityisen typerä olin elätellessäni haaveita Rione Toianon tutkimisesta. He maalailivat kuvaa naapurustossa piilevästä täysin erilaisesta maailmasta, osittain varmaan naiiviuteni inspiroimina. Toianolaiset olivat heidän luonnehdinnoissaan milloin vaarallisia rikollisia, milloin pelokkaita, sekä "tietämättömiä" että ovelia huijareita. Perheeni korosti erilaisuuttaan, joten kaikki siihen asti oppimani vaikutti joko liian yleiseltä tai liian erityiseltä. Kuvaavaa on, että kuvittelin naapurin rouvan sukunimen olevan Fianco, ja vasta myöhemmin, kuultuani sanonnan "la signora a fianco" muissakin keittiöissä, ymmärsin sen tarkoittavan ketä tahansa vieressä asuvaa naapurin rouvaa. Italian ja murteen välinen ero tekee kielen oppimisesta varsin kuvaavan esimerkin muulle oppimiselle.

Muistiinpanoni kertoivat tyypillisimmin keskusteluista: "tänään puhuttiin siitä, kuinka...", "Maria sanoi...". Ilman selityksiä ymmärsin kovin vähän. Arkisesta elämästä erottuvia tapahtumia tuntui olevan kovin vähän dokumentoivaksi, kotitöihin en saanut osallistua, vieraita kävi harvoin, en käynyt perheenjäsenten kanssa juuri muualla kuin satunnaisesti kirkossa ja lähiön viikoittaisilla markkinoilla. Osallistuvan havainnoinnin opetus oli se, että sain osallistua vain vähän.

Signora Fiancon perheineen tunsin ulkonäöltä ja juorujen kautta, muihin naapureihin en tutustunut koska odotin turhaan otollista hetkeä. Yhdeksän perheen asuttamassa rappukäytävässä on yllättävän vaikea tunnistaa ihmisiä edes ulkonäöltä, varsinkin, kun asukkaita oli perheiden suuruuden takia ehkä kuutisenkymmentä. Lopulta isäntäperheeni antoi ymmärtää, että minun olisi parasta pysytellä pahojen puheiden takia kaukana naapureista. Perheeni 14-vuotias tytär tarjoutui auttamaan minua, äitinsä suostumuksella hän käytti minua tekemässä "pikku tutkimustani" kolmen muualla asuvan naisen luona, lisäksi signora Fiancon arka tytär, poloinen, komennettiin haastateltavakseni.

Toianolaisten naisten (minulle) sulkeutuneet kasvot ja (minulle) käsittämättömät murteen ryöpsähdykset saivat minut välillä uskomaan isäntäperheeni varoituksia haa- 


\section{AnNa-Maria TAPANinen}

veitteni mahdottomuudesta - ja samalla uhmaamaan niitä. Koin melkein huimaavaa uteliaisuutta kenttätyötä tehneille tutun epätoivon tunteen keskellä. Kuulemani ja näkemäni ei niinkään tarjonnut vastauksia kuin herätti yhä uusia kysymyksiä. Ennakko-oletukseni vaikuttivat miltei merkityksettömiltä. Tämä ei kuitenkaan tarkoita naturalistisen käsityksen mukaista, tyhjentymisharjoituksesta seuraavaa herkkää ja luotettavaa rekisteröintikykyä. Pikemminkin on kyse "onnistuneen disorientaation" mahdollisuudesta (Lederman 1990, 86). Toisaalta, kuten tulin sittemmin huomaamaan, olinkin oppinut kuulostelemaan, hahmottamaan ja kertomaan asioita, joilla oli merkitystä myös kotikeittiön ulkopuolella. Olisi ollut jopa ajattelematonta ryhtyä töihin aikaisemmin: en olisi tajunnut asemaani liittyviä ongelmia, vuorovaikutuksen vivahteista puhumattakaan.

\section{SAAPUMISIA}

Odottelu päättyi varsin intensiiviseen ja epäkonventionaaliseen kenttätyövaiheeseen: ovelta ovelle kiertämiseen, aluksi pareittain, sitten yksin, lyhyen haastattelulomakkeen suojissa. Menetelmäoppaiden mukaan luottamuksen saavuttaminen edeltää onnistuneita haastatteluja. Oli varsin provosoivaa sekä menetelmäohjeiden että Toianon oppien jälkeen soittaa "suljettujen eteläitalialaisten perheiden" ovikelloja, esittäytyä "pelokkaille" ja "tietämättömille" ventovieraille ihmisille ja aloittaa tapaaminen ronskisti lomakehaastattelulla. Urbaanille antropologialle tyypilliset lähestymistavat olivat osoittautuneet mahdottomiksi. En voinut kuvitella "hengailevani" (ks. Whyte 1996 [1955]) kaduilla. Toinen yleinen vaihtoehto, sosiaalisten verkostojen seuraaminen esimerkiksi naisten naapurustoihin asettumalla, oli jo osoittautunut kaikkea muuta kuin luontevaksi.

Kenttätyötä jouduttaaksemme oli turvauduttava hienovaraisen lähestymisen sijasta anonyymeihin yllätyshyökkäyksiin. Olen luonnehtinut lähestymistapaani "donquijotemaiseksi suljettujen ovien haastamiseksi" (Tapaninen 1996, 10). Tämä kuvaa myös haastattelujen konkretiaa, sillä jouduin usein esittämään asiani suljetun oven läpi tai oven raosta. Vaikka lähestymistapa oli usein turhauttava, en osannut luopua siitä myöhemminkään. Aineiston keruu ja metodi tuntuvat käsitteinä huonosti sopivan siihen kuvaan, joka välittyy muistiinpanoistani. Tarjouduin summittaisesti ventovieraiden ihmisten vieraaksi, ikään kuin sanoen: "Tässä minä olen, olen muukalainen mutta kunnon tyttö, haluaisin puhua rouvan kanssa." Mitä selitinkin, kuvittelisin, että pyyntöni vetosi pääasiassa naisten uteliaisuuteen. Tarjosin poikkeuksellista iltapäivän viihdykettä ja herätin myötätuntoa. Parikymmentä minuuttia kestänyt lomakehaastattelu, suppeahko kotitalouskysely, oli molemminpuolisen tunnustelun vaihe. Sen jälkeen minut otettiin vastaan vieraana, ja vieraan ei sovi tietenkään kysyä mitä vain. Ensimmäistä tapaamista mahdollisesti seuraavia haastatteluja rajoittivat kohtuullisuuden kriteerit. Siksi mahdollisimman tarkan haastattelumateriaalin saaminen ei voinut olla tavoitteenani.

Kenttätyön osana on usein haastatteluja. Haastattelemista voidaan pitää osallistuvan havainnoinnin lailla yhtenä kenttätyömenetelmänä. Yhtä perusteltua, mielestäni 
osuvampaa, olisi nähdä haastattelut osallistuvaksi havainnoinniksi nimetyn strategian yhtenä osana (ks. Wolcott 1995). Haastatteleminen on kenttätyön aktiivinen ja tietyssä mielessä tehokas, helppokin osa. Se kartuttaa väistämättä aineistoa, ja siksi haastattelut voivat kompensoida kenttätyön puutteita. Jos ne asetettaisiin etuoikeutettuun asemaan, heräisi kysymys kenttätyön mielekkyydestä: olisi varmaan vaivattomampia ja tehokkaampia tapoja tehdä haastattelututkimusta. Caterina totesi vuosien jälkeen, että olin onnistunut valloittamaan toianolaiset kahdesta syystä: minulle, tietämättömälle, saattoi valehdella ja toisaalta minulle, ulkopuoliselle, saattoi puhua vapaasti aroistakin asioista.

Miellänkin haastatteluni tapahtumina kolmessa merkityksessä. Ensinnäkin ne koostuivat yhtä lailla keskusteluista kahvikupillisen ääressä kuin varsinaisesta haastattelusta. Muut läsnäolijat (keskimäärin kolme, neljä) tekivät niistä sosiaalisia tapahtumia, vierailuja ja rupatteluhetkiä. Ne ajoittuivat lounaan jälkeisen siivouksen ja illallisen valmistamisen väliseen aikaan, jolloin naiset tapaavat muutenkin piipahtaa toistensa luona. Toianolaisille naisille ne olivat näissä tutuissa puitteissa poikkeuksellisia tapahtumia. Monet keskustelivat ensimmäisen kerran ulkomaalaisen kanssa. Toiseksi ne olivat tapahtumia siksi, että kukin oli omalaatuinen, näitä puitteita lukuun ottamatta minun on vaikea luonnostella tyypillistä haastatteluhetkeä. Myös samoja naisia toistuvasti tavatessani tilanteet ja tunnelmat vaihtelivat. Kolmanneksi haastattelut sijoittuvat osaksi niitä tapahtumia, joista kenttätyö koostuu. Ne muodostavat aineistoni keskeisen ja parhaiten dokumentoidun osan. Haastattelujen, niiden liepeillä käytyjen keskustelujen, keittiövierailuissa syntyneiden havaintojen ja muun kenttätyön välillä ei ole kuitenkaan selviä eroja.

Käytin keskusteluissa toisten naisten väitteitä, ilmaisuja ja sanoja kuin täkyjä - osittain strategiana, koska halusin tietää, mikä keittiöitä yhdistää tai erottaa, osittain siksi, että näin olin oppinut puhumaan. Ja usein sain samankaltaisia vastauksia esimerkiksi naapuruutta koskeviin kysymyksiin: "Sanomme vain hyvää päivää, ei muuta." Isäntäperheeni lailla muutkin toianolaiset pitivät tutkimuskohdettani jopa epäilyttävänä. Naapureita väitettiin melkein yhteen ääneen pahoiksi, rahvaaksi ja vaarallisiksikin. Kuulin myös samoja suuria mutta arkisia sanoja käytettävän erilaisissa yhteyksissä: emansipaatio, modernisuus, vapaus, kurjuus, etelä ja pohjoinen. Näistä asioista oli keskusteltu aikaisemminkin. Paikalla olleet naiset täydensivät toistensa tarinoita ja lauseita, referoivat aiempia keskusteluja, kertoivat samanlaisia tiivistettyjä tarinoita yhteisistä suurista aiheista kuten kihlautumisesta, Toianoon muutosta tai Pozzuolin menneisyydestä.

Naiset tarjosivat minulle tarinoita (kärsimys- ja sankaruuskertomuksia), herkullisia anekdootteja ('ja sitten yksi toinen episodi, haluatko kuulla"), analyysejä (kommentoitavaksi), oikeaoppisia vastauksia kysymyksiini ("puhuimmeko hyvin", "katsotaan, osaanko vastata"), kysymyksiä ("voimmeko puhua vähän... seksistä") sekä rupatteluhetkiä. Joskus paikalla olijat intoutuivat keskustelemaan keskenään, ja minä jäin sivulliseksi. Joskus puutteellinen kielitaitoni, etenkin kyvyttömyyteeni murteellisen kommunikaation repertoaarien tajuun, teki minusta etuoikeutetun tutkijan sijasta ulkopuolisen hölmön. Huolimatta ilmeisestä sosiaalisesta ja kielellisestä kömpelyydestäni en suostunut tekemään varsinaisia teemahaastatteluja vaan yritin itsepintaisesti luovia keskustelun johdattelemisen ja sen aktiivisen seuraamisen välissä. Yritin hahmottaa 


\section{AnNa-Maria TAPANinen}

kulloisenkin virityksen ja sen muutokset, minkä takia keskustelujen luonne vaihteli tilannekohtaisesti - puheenaiheet, painopisteet, oma aktiivisuuteni, kesto, käytetty kieli (italia ja murre), jopa se, kuka kysyi ja vastasi. Naisten elämäntarinat ja arkielämän rutiinien kuvaukset muodostivat haastatteluille vain väljän rungon. Tapaamiset olivat siis enemmän kuin haastatteluja.

Keskustelujen fraseologisuus yhdistyi ristiriitaisuuteen, tai, paremminkin, kompleksisuuteen. Kysymys naisten keskinäisestä samanlaisuudesta tai erilaisuudesta ei tavoittaisi olennaista seikkaa: liikettä. Koska keskusteluissa oli lähes aina läsnä myös muita ihmisiä, italiasta siirryttiin helposti murteeseen, yleistyksistä yksityiskohtaisiin kuvauksiin ja argumenteista vastaväitteisiin. Kenttätyön edetessä opin myös ennakoimaan ja provosoimaankin näitä siirtymiä. Niissä tapaamisissa, jotka rajoittuivat kahdenkeskiseen haastatteluun, oli vähemmän vaihteluihin innoittaneita tekijöitä.

Erilaiset puheet eivät kuvaa totuudenmukaisuuden eri asteita. Intensiivisen kenttätyön idean yhtenä perustana on käsitys sosiaalisen elämän kompleksisuudesta, joka ei ole pelkistettävissä valheisiin, näennäisyyksiin ja perimmäisiin totuuksiin. Yhtenä opetuksena voikin olla, että neutraalia tarkkailupistettä ei ole olemassa, ja sikäli ei voida myöskään puhua objektiivisesta, "ei-mistään" käsin rakentuvasta tiedosta (ks. Bourdieu 1990; Jenkins 1994). Tutkijan persoonan tislaaminen pois perustuu käsitykseen siitä, että tutkimuksen subjektin subjektiivisuus estää näkemästä objektia selvästi ja totuudenmukaisesti. Tällöin oletetaan, että sosiaalisella elämällä tai tutkittavilla ihmisiä olisi yksi, tosi olemus irrallaan sosiaalisuudesta. Yhtä lailla perusteetonta olisi redusoida vaihtelu vuorovaikutukseen tutkijan ja tutkittavien välillä. Tällöin sosiaalinen todellisuus pelkistyy vuorovaikutuksen dynamiikaksi ja tulkinnan varsin todelliset ongelmat kätkeytyvät intersubjektiivisuuden ja dialogien ideoiden taakse (ks. Comaroff \& Comaroff 1992, 7-13; Fardon 1990). Kenttätyön keston takia asiat eivät pelkästään selkiinny vaan myös monimutkaistuvat. Tämä koskee myös tutkijan omaa asemaa, se ei ole kenttätyössä yksiselitteinen eikä pysyvä. Tutkijat ovat havainnoijina ulkopuolisia, ja tämän merkitystä ei voida neutralisoida pohtimalla iän, sukupuolen ja muiden sosiologisten taustamuuttujien merkitystä. Kuten Pierre Bourdieu (esim. 1990, 27) on osoittanut, kyse ei ole niinkään näkökulmien erilaisuudesta ja relatiivisuudesta vaan siitä, että tutkijat ylipäätään ottavat näkökulman suhteessa kohteeseen, objektiin.

Osallistumistani konventionaalisessa merkityksessä köyhdytti se, että minua ei voinut sijoittaa paikallisten positioiden puitteissa, mutta tämä anonymiteetti kevensi kohtaamisia ja joissakin tapauksissa ehkä avasi minulle oviakin. Joskus kepeys voi olla tavoiteltavampaa kuin syvyys. Omituisen asemani turvin pystyin tutustumaan erilaisiin naisiin ja jopa ottamaan epäsuorasti osaa heidän välisiinsä keskusteluihin ja kiistoihin. Keittiöitä samanaikaisesti yhdistävien ja erottavien tekijöiden kautta aloin hahmottaa sitä sosiaalista maailmaa, jonka liepeillä olin. 


\section{SINNE JA TAKAISIN: LÄHIÖKENTTÄTYÖSTÄ KAUPUNKIETNOGRAFIAAN}

\section{MATKAN JÄLKIÄ}

\section{Aineiston sirpaleita}

Kenttätyössä olennaista on sitä seuraava kertomus, etnografia (Wolcott 1995, 66-67), ja siksi kenttätyön arvo määrittyy takautuvasti. Etnografinen asennoitumiseni johti tietynlaisiin lähestymistapoihin jo kenttätyön aikana, mutta vasta kirjoitusvaiheessa tapahtui ratkaiseva siirtymä, toinen loikkaus. Tämä kyseenalaisti menetelmäni ilmeisimmät perusteet. Pitkälti haastatteluihin perustunut kenttätyö alkoi muokkaantua haastattelututkimuksen sijasta etnografiaksi.

Kenttätyö voi vaikuttaa tunkeutumiselta, paljastamiselta, menemiseltä niin ulkopuolisten kuin paikallistenkin käsitysten ja esitysten tuolle puolen, näennäisestä todelliseen. Osallistuvan havainnoinnin idea Malinowskin muotoilemana korosti havainnoitavan todellisuuden keskeisyyttä verrattuna verbaalisesti esitetyn näennäisyyteen. Antropologisessa visualismissa nähty oli totta (Hastrup 1986), mutta käsitys kentän ulkopuolelta kuin katsomosta havainnoimisesta on kyseenalaistunut niin kentän konstruointia kuin antropologista tietoakin koskevassa kriittisessä keskustelussa (Clifford 1986). Tutkijoiden ja tutkittavien välisen suhteen dialogisuus on noussut keskeiseksi, joskin ongelmalliseksi metaforaksi. Kun etuoikeutettuun asemaan asetetaan keskustelut havainnoinnin sijasta, myös käsitys näennäisen takaisesta todellisuudesta paikantuu kokemuksistaan puhuviin ihmisiin.

Tämä käänne voi tehdä myös lähiöetnografian välttämättömyyksistä hyveitä. Jos "kuvitteellinen hahmo yksinäisestä kenttätyön tekijästä yksinkertaisessa yhteiskunnassa palaa kummittelemaan fragmentoituneelle kenttätyöläiselle kompleksisessa yhteiskunnassa" (Strathern 1991, 24), nyt tiedämme, että tämä vaikeasti karkotettava haamu ei ehkä olekaan kenttänsä maisemaan sulautunut malinowskilainen hahmo vaan monografian kirjoittajan (oma)kuva. Juuri tämä kummitus, oikean kentän ja kenttätyön kuvajainen, on voinut saada minutkin taistelemaan suljettuja ovia vastaan ja miettimään, että olisin parempi tutkimukseni niin sanottu instrumentti röntgenkatseella varustettuna.

Kenttämatkan tuliaisina on aineistoa: muistiinpanoja, nauhoja, transkriptioita, tekstejä, kuvia, dokumentteja. Aineellisuudestaan huolimatta tämä sekalainen rypäs ei muodosta samanlaisena pysyvää faktojen kokoelmaa. Se ei ole ääretön varanto mutta ei myöskään täysin rajallinen. Aineiston laatu ja määrä eivät pysy vakioina. Muistiinpanojen osana ja lisänä on joukko vain viittauksenomaisia tai ei lainkaan kirjattuja, kenties luonteeltaan jäsentymättömiä muistikuvia. Näistä Simon Ottenberg (1991) on käyttänyt nimitystä headnotes, käsite, jonka voisi suomentaa erotukseksi muistiinpanoista "merkille panoina". Ne ovat olemassa jatkuvasti muuttuvina niin kauan kuin etnografikin. On myös mahdollista kirjoittaa etnografia vaikka aineisto olisi tuhoutunut tai hävinnyt; Edmund Leachin klassikko Political Systems of Highland Burma (1954) syntyi vaikka tutkimusaineisto oli hävinnyt.

Muistiinpanot uhmaavat muistia, toimivat vaalimaamme kokonaiskuvaa vastaan, osoittavat aukkoja ja ristiriitaisuuksia (Lederman 1990, 73). Etnografisessa tutkimuksessa näihin on suhtauduttava kenties tavallista vakavammin, mietittävä, missä määrin ristiriitoja ei voi selittää pois, missä määrin ne taas määrittyvät ristiriitaisiksi vain suh- 


\section{Anna-Maria Tapaninen}

teessa abstrakteihin tulkintoihimme ja erikoiseen näkökulmaamme. Vaikka kysymys aineiston riittävyydestä on mitä tärkein, tiedon ja ymmärryksen rajat määrittyvät tätä yleisemmällä tasolla. Oma aineistoni on auttamattoman niukka, mutta en tiedä, mitä mittaisin: sivuja, kasetteja, tunteja, naisia, perheitä, kuukausia, vuosia?

Kenttätyö kielikylpynä ja sosiaalisena kylpynä usuttaa tutkijaa jatkuvasti samojen kysymysten äärelle: mikä on tämän erityisyys tai yleisyys, miten tämä on erilainen tai samanlainen. Signora Fianco olikin siis yksi signora a fianco, "kylkinaapurina" asuva rouva. Hänen sukunimensä ei selviä oven nimikylttiä lukemalla, sillä niissä on vain miehen sukunimi. Toianolaiset (keski-ikäiset pozzuolilaiset? alaluokkaiset napolilaiset?) rouvat käyttävät kuitenkin tyypillisesti, kenties poikkeuksetta, tyttönimeään. Myös seiniin liimattavissa kuolinilmoituksissa naisista käytetään omaa sukunimeä. Tämän alla on usein sana mogliata tai vedova ja miehen sukunimi. Joskus, etenkin miesten kohdalla, ilmoituksessa saattaa olla lisäksi murteellinen lisänimi. Napolin sanomalehdessä Il Mattinossa kuolinilmoitussivut ovat keski- tai yläluokkaisten vainajien lukuisten kuolin-, vuosipäivä- ja osanottoilmoitusten täyttämiä. Näissä naisista käytetään kolmenlaisia sukunimiä: yleisimmin ehkä miehen sukunimeä, mutta myös kaksiosaisia sukunimiä ja tyttönimiä. Toianolaisten kuolinilmoitukset päätynevät kuitenkin hyvin harvoin, jos koskaan, sanomalehteen. Paikalliseen käytäntöön ei tunnu liittyvän selviä, ainakaan eksplikoitavissa olevia, sääntöjä, vaikka se vaikuttaakin johdonmukaiselta.

Lähiympäristön rahvaan katsottiin elävän uppiniskaisesti entiseen tapaan, he olivat tuoneet entisten köyhälistökortteleiden maailman mukanaan Toianoon. Naiset kertoivat pitävänsä kuitenkin yllä kohteliaita välejä "hyviin" naapureihinsa. Usein näihin viitatessa käytetään signora-attribuuttia. Kävi myös ilmi, että aikaisemmin naapureita oli kutsuttu etunimeltä tai lempinimillä rouvittelemisen sijasta. Signora Rosa kertoi:

Mutta esimerkiksi täällä kaikki kutsuvat minua signoraksi, ei kukaan nimeltä. Ainoastaan yksi alakerran rouva, koska tunnemme toisemme, hän asui samassa talossa San Giuseppessa - - ja hän aina välillä huutaa alhaalta: "Rusí!" Mutta kaikki muut kutsuvat minua signora Cannavaroksi. Mutta en minä ole signora...

Tämä oli yksi merkki menneisyyden ja nykyisyyden välisestä katkoksesta, "avoimien ovien" sulkeutumisesta.

Etäisyyden sällyttäminen signora a fiancoon kertoo nykyisyydestä, joka tulee ymmärrettäväksi vain menneisyydestä käsin. Ilmaisu ei ole italiankielisessä asussakaan yleinen vaan ilmeisesti eteläitalialainen, leimallisesti napolilainen ja Napolissakin alaluokkainen, samoin kuin porte a porte, 'ovi oven vieressä'. Myös nykyiset sosiaalisuuden muodot ovat näin kytköksissä näihin entisiin, ahtaasti rakennettuihin ympäristöihin. Puheet sosiaalisesta etäisyydestä tai naisten "suljetusta" luonteesta yhtä lailla kuin "eteläitalialaisesta" hyväsydämisyydestä tai avoimuudesta eivät ole näin kontekstualisoituina ristiriitaisia. Kun eräs nainen kertoi pitävänsä "huolen vain omista asioistaan", hän tähdensi tätä väitettään kertomalla olevansa tietämätön siitä, "miten signora [a fianco] kodissaan elää". Tällainen seikka on tosiaankin mainitsemisen arvoinen. 
Kun tutkimukseni on jatkuvasti kierrellyt naisten arkielämän ympärillä, on ilmeistä, että tähän valitsemani konkreettiset esimerkit eivät ole merkityksettömiä. Vaikka näin ei olisikaan, tämän kaltainen kokemuksellinen tieto olisi osa ymmärrystä tutkittavan maailman materiaalisestakin todellisuudesta. Samalla ennustettavuus on kuitenkin rajallista. Vähintään yhtä keskeistä on edellä mainitsemani jatkuva, välillä hyvinkin korostunut, vaihtelu ja ennakoimattomuus, myös sattumat.

Naapuruutta koskevien väitteiden ymmärtäminen ei voi tapahtua haastatteluja systemaattisesti analysoimalla vaan yksinkertaisiakin käsitteitä ja idiomeja kontekstualisoimalla. Naisten väliset keskustelut keittiöissä, näkymät rupattelusta siivousaikoina parvekkeilta toisille, juorut, naisten puhetavat markkinoilla ja busseissa sekä käsittämättömätkin murteelliset ryöpsähdykset yhdistyvät varsinaisten haastattelujen siirtymiin ulkopuolisen ja sisäpuolisen perspektiivin välillä. Murteen ja yleiskielen rajaa ei piirrä mikään yhtä vahvasti kuin kielen fyysisyys, joka näkyy myös asennoissa, äänessä ja eleissä. Erilaiset puhetavat kantavat mukanaan erilaisia maailmoja ja tapoja ottaa paikka niissä. On onnekasta, että tämä näkyy suhteellisen kurittomissa haastatteluissakin.

Voisin jatkaa signora Fianco -esimerkin pohtimista niin pitkään, että puhuttelujen, puheiden ja nimien kontekstualisointi johtaisi lopulta tiivistelmään tutkimuksestani. Jääköön tulkinta kuitenkin esimerkkien tasolle. Olen yrittänyt näiden havaintojen kautta kuvata sitä, miten tieto karttuu kenttätyön aikana vähän kerrallaan, usein näennäisen merkityksettömistä yksityiskohdista. Näiden relevanssi muokkaantuu tulkintojen myötä, ja samalla muistikuvatkin saattavat muokkaantua aineistoksi. Haamuaineisto ei välttämättä koostu epämääräisistä ja epäluotettavista muistikuvista ja tuntemuksista vaan, kuten tässä esitellyissä vinjeteissäkin, arkisesta konkretiasta. Signora-attribuutin käytöstä on tietysti esimerkkejä haastatteluissani, mutta näiden läpikäymisen ohella rouvittelun merkitysten ymmärtäminen edellyttäisi myös erilaisten tilanteiden mieleen palauttamista. Tieto voi perustua asioihin, joista ei ole tullut tehneeksi tarkkoja merkintöjä. Monet sosiaalisen elämän kannalta keskeiset seikat ovat luonteeltaan sellaisia, että niistä ei voi jäädä selkeitä jälkiä aineistoon. Kenttätyön tieto tarjoaa sekä vähemmän että enemmän kuin kontrolloitu aineisto.

\section{Kobtaamisten opetuksia}

Toianon ongelmallisen ja jännittävän sosiaalisen maailman hahmottamiseksi olen luopunut empiristisestä tarkkuudesta ja systemaattisuudesta. Tai, toisin sanoen, olen laventanut empiiristä otettani. Kiertelyni Napolin keskustan köyhälistökortteleissa antoivat jonkinlaista tuntumaa vanhojen kortteleiden vilkkaaseen katuelämään ja aistittavaan yksityisyyteen. Naisten huudot, tapa ottaa kadut itsetietoisesti haltuun ja satunnaiset kohtaamiset naisten kanssa, jotka saattoivat yhtä lailla yrittää karkottaa minua korttelista kuin kutsua minut puheilleen, kertoivat Toianonkin sosiaalisuuden kannalta tärkeistä seikoista. Näiden satunnaisten tapaamisten ohella olen tietysti lukenut Napolia koskevia tutkimuksia, myös historiallisia tutkimuksia, jotka ovat rikastaneet etnografista preseesensiä. Kodin ja kadun välinen ero on näiden konkreettisten ja kirjallisten ekskursioiden kautta tullut uusilla tavoilla keskeiseksi. Toianossa asuessani olen sovittanut tiedostamattanikin, omalla kömpelöllä tavallani, tottumuksiini eron keskeisyyden. Aineistokeskeisen empirismin sijasta empiirinen tutkimukseni on pe- 


\section{Anna-Maria Tapaninen}

rustunut myös laajoihin kontekstualisointeihin ja omakohtaisiin kokemuksiin. Tämä ei kuitenkaan tarkoita sitä, ettei kiinnekohtana olisi ollut koko ajan Rione Toianon sosiaalinen todellisuus. Siinä kokemuksellinen ja tulkinnallisesti keskeinen kohtaavat, onneksi myös varsinaisen aineiston tasolla.

Aineiston epämääräiset rajat eivät tee etnografisesta tutkimuksesta kuritonta ja impressionistista, pikemminkin päinvastoin. Niin naiivi realismi kuin äärimmäinen skeptisyyskin kyseenalaistuvat, kun aineiston tulkinnan ääressä joutuu ja pystyy pohtimaan sen suhdetta kaikkeen siihen, joka ei syystä tai toisesta ole muokkaantunut varsinaiseksi aineistoksi. Tieto ei voi olla objektiivista ainakaan absoluuttisessa merkityksessä, mutta ei myöskään subjektiivista, vaan yhdistelmä realismia ja refleksiivisyyttä (ks. Knauft 1996). Sosiaalinen todellisuus kenttätyössäkään ei ole läpinäkyvää - ikään kuin kokoelma keräämistä odottavia faktoja - mutta ei myöskään mielikuvituksen tuotetta. Faubion $(2001,44)$ on todennut osuvasti, että kenttätyössä todiste tulkintojen luotettavuudesta rakentuu performatiivisesti, kyvyssä olla vuorovaikutuksessa tutkittavien ihmisten kanssa.

Johannes Fabian (1994) on esittänyt, että etnografian yhteydessä voidaan puhua objektiivisuudesta, mikäli sovelletaan objektiivisuuden prosessuaalista tai dialektista näkemystä. Prosessi voi alkaa ainoastaan kohdatessaan vastustusta, ymmärryksen rajoja, kieltämistä, torjumista, "tai, miksi ei, silkkaa Toiseutta" (mts. 94). Tieto prosessina saa Fabianin mukaan alkunsa konfrontaatioista ja näihin liittyvästä kommunikaatiosta. Käsite konfrontaatio, "otsakkaisuus", konnotoi kiistanalaisuutta, ja siksi se kyseenalaistaa naiivit käsitykset kommunikaation neutraalisuudesta tai eettisestä itseisarvosta. Omassa kenttätyössäni esimerkiksi neuvottelut soveliaasta korvauksesta perheessä asumisesta, vieraanvaraisuuden koukerot, suljettujen ovien haastaminen, pakotettu anonyymius, naapurin rouvien kohtaamisen sosiaalinen koreografia tai toistuvat keskustelut tutkimuskohteeni ongelmallisuudesta objektivoivat Fabianin merkityksessä minulle toianolaista todellisuutta. Nämä jatkuvasti toistuvat kohtaamiset ja rajankäynnit toivat tietoa, jota ei voisi saavuttaa kuin tosiasioita etäältä havainnoiden, mutta ei myöskään dialogien kautta käsitteen suppeassa, eettisessä merkityksessä. Ilman läsnäoloani näitä kohtaamisia ei olisi ollut, mutta olisi mieletöntä väittää, että kokemukset olisivat subjektiivisia.

Vaikka absoluuttinen tieto toisten kokemuksista ja toimista on mahdotonta, kenttätyö perustuu kommunikaation ja ymmärryksen pragmaattisiin mahdollisuuksiin, jotka ovat yleensäkin sosiaalisen elämisen perusta (Knauft 1996, 46-47). Täten etnografian refleksiivisyys edellyttää sekä kiinnittymistä ulkoisen todellisuuden objektiivisuuteen että epistemologiseen, näkökulmien relatiivisuuteen. Kenttätyön empiirisyys kattaa koko sen maailman, jonka materiaalisen ja sosiaalisen todellisuuden keskellä tai ainakin liepeillä tutkija tietää hetken erikoisella tavalla eläneensä. Etnografisen kirjoittamisen perinteiden mukaisesti tämän todellisuuden olisi päädyttävä mahdollisimman rikkaana myös etnografiaan, ei pelkästään analysoituna vaan myös kuvattuna. Tässä piilee kuitenkin uusia ongelmia. 


\section{IKÄÄN KUIN MAISEMA}

"Mikä siis on tämä etnografin taikuus, jonka kautta hän pystyy manaamaan esiin alkuasukkaiden todellisen hengen, heimoelämän totuudenmukaisen kuvan?” (Malinowski 1961, 6). Jo kenttätyön pitkäaikaisuutta ja intensiivisyyttä korostavat ideaalit luovat etnografialle naturalismia ja realismia tai kenties eksperimentaalista positivismia (Fardon 1990) lähentyviä tavoitteita. Kysymys autenttisuudesta ei ole sivuutettavissa. Autenttisuuden luominen näyttäytyy kuitenkin tulkinnallisena haasteena. Crapanzano (1986) onkin verrannut etnografeja Hermekseen, sanansaattajaan, jonka on tehtävä viestinsä vakuuttavaksi. Etnografi on paradoksaalisen asemansa vanki: hänen on tehtävä vieraasta ymmärrettävää, siis ylitettävä vieraus, ja samalla säilytettävä tämä samainen vieraus, jonka hän juuri tulkinnallaan kieltää. "'Meidän on luotava todellisuus uudessa muodossa, jotta se voisi puhua puolestaan" (Hastrup 1986, 13).

Pelkän totuuden kertominen ei ole mahdollista siitäkään syystä, että kenttätyön kautta opittu tieto on samanaikaisesti sekä moninaisuudessaan ylenpalttista että jo tulkittua, ei joukko raakoja faktoja. Lyhyestäkin kenttätyöstä voisi syntyä monenlaisia tarinoita. Vaikka totuuksien ja tulkintojen osittaisuus on yleinen tosiasia, etnografioissa tekstualisoinnin ongelmat näyttäytyvät erityisen vakavina. Jo se, että aineiston keruu, analyysi ja kirjoittaminen eivät ole erillisiä vaiheita, edellyttää palaamista kenttätyöhön - toki jo muokkaantuneessa ja tulkitussa muodossa - myös kirjoitusvaiheessa. Siten todellisuuden kaikkoamisen tunne voi huolestuttaa juuri silloin kun aineisto alkaa jäsentyä, ja jo tämä voi saada palaamaan kentälle, ei pelkästään tarve saada lisää aineistoa.

Yksityiskohtaisinkaan kuvaus ei ole silminnähtävän tai ilmeisen selventämistä, näkyväksi tekemistä ja sanoiksi pukemista vaan potentiaalisuuden tavoittelemista, joka perustuu antropologiseen mielikuvitukseen (Hastrup 1995, 68-70). Etnografian maailman konstruointi merkitsee etäältä ja ulkoa käsin hahmottuvaa kuvauksen kohdetta. Objektivointi on tässä mielessä väistämätöntä, mutta se pitää sisällään useita vaihtoehtoja. Vaikka holismi perinteisessä kattavuuden merkityksessä on käynyt mahdottomaksi (ks. Ortner 1995), etnografia on kuitenkin yhteyksien rakentamista suhteessa johonkin kuviteltuun kokonaisuuteen. Kuten Thornton $(1988,289)$ on huomauttanut, tämä tapahtuu retorisesti: "kokonaisuuksien fiktio" takaa "'faktojen' faktuaalisuuden".

Etnografisen tiedon kytkeytyminen "alkuasukkaan näkökulmaan" (Malinowski 1961) ei voi perustua siihen, että etnografi olisi "empatian, tahdikkuuden, kärsivällisyyden ja kosmopoliittisuuden kävelevä ihme" (Geertz 1983, 56). Etnografit eivät ole toinen toistaan parempia tai sensitiivisempiä ihmisiä ja sen takia hyviä tutkijoita. Nämä ominaisuudet ovat tärkeitä mutta ymmärrys ei voi perustua yksin niihin.

Mikä siis on alkuasukkaan näkökulma, keitä se koskee, millaisena se näyttäytyy? Miten mahduttaa kaikki naapurin rouvat ja isäntäperheeni samaan etnografiaan huolimatta heidän haluttomuudestaan? Monet toianolaiset naiset olivat huolissaan siitä, että yhdistäisin heidät naapureihin marginaalisen lähiön muodostaman yhteisen nimittäjän kautta ja, "pohjoisuuteni”" sokaisemana, näkisin vain tämän marginaalisuuden ja takapajuisuuden kiinnittämättä huomiota eroihin ja muutoksiin. Toisaalta luokitteleminen, jopa paikallisin termein, olisi ollut paitsi väärä myös pohjimmiltaan loukkaava ratkaisu. 


\section{Anna-Maria Tapaninen}

Kontekstualisoinnin tapa ratkaisee, miten naisten väliset erot ja samankaltaisuudet suhteutuvat toisiinsa, missä määrin yhtäältä sosiaalisen elämän vakavuus ja toisaalta sen sisältämä liikkumavara korostuvat. Kenttätyötä väitetään usein intiimiksi, mutta etnografioiden tietoa luonnehtii pikemminkin sensitiivisyys. Olen päätynyt etnografiassani vain raottamaan toianolaisia "suljettuja ovia", ja isäntäperheeni kotikin näyttäytyy vain yhtenä keittiönä toisten joukossa. Kaikista väitöskirjassani esiintyvistä miehistä olen käyttänyt pseudonyymiä Gennaro Napolin ja Pozzuolin tärkeimmän suojeluspyhimyksen mukaan korostaakseni tietojeni puutteellisuutta, ja nyt olen miettinyt, että signora-arvonimen käyttö minua vanhempien naisten pseudonyymien yhteydessä olisi ollut samalla tavalla rehtiä.

Etnografiani on kuvaus toianolaisten rouvien jakamasta maailmasta, niin arkielämän käytänteistä kuin eri tavoin niitä ymmärrettäväksi tekevistä puheistakin. Vaikka etnografian täyttäisivätkin yksittäiset ihmiset etunimineen ja persoonallisine äänineen, he eivät voi puhua suoraan lukijalle. Etnografiassani oli esimerkiksi selvitettävä, mistä toianolaiset naiset puhuvat puhuessaan naapurin rouvista ja mitä kaikkea rouvuus Rione Toianossa tarkoittaa erityisessä, vuosituhannen vaihteeseen sijoittuvassa etnografisessa preesensissä. Ja tämä voi tapahtua vain kontekstualisoimalla, tekemällä valintoja joiden kautta voi manata esiin tietynlaisen maailman etnografista kertomusta jäsentämään. Valinnat luovat erilaisia dynaamisuuden ja/tai staattisuuden muotoja arkielämän kuvaukseen. Kuvauksen tiheys (Geertz 1973) pohjautuu niin silmää räpäyttämättä minulle esitettyihin väitteisiin naapurin rouvien omituisuudesta kuin rouvien välisen kanssakäymisen silmäniskujen kaltaisiin, leikkisiin, ironisiin tai kodikkaisiin hetkiin.

Toianolainen rouvuus ei ole pelkkää sosiaalista kitkaa, joka kertoisi vanhan yhteisöllisyyden häviämisestä hetkeä ennen modernisoitumista. Mutta kyse ei ole myöskään (eteläitalialaiseen? napolilaiseen?) kulttuuriin piintyneistä piirteistä. Pikemminkin näkisin etnografiani tehtävänä olevan tietyn historiallisen tilanteen kuvaamisen. Marc Augén (1997) kirjan italiankielistä nimeä lainatakseni, kyse on "nykyisyyden historioista/tarinoista". Kun Caterina arvosteli minua jälleen kerran, vuosien jälkeen, arveluttavan tutkimuskohteen valinnasta, puolustauduin kertomalla, että tutkimukseni ei kotielämään rajoittuessaan esitä huonoa kuvaa (brutta figura) Toianosta. Ensin hän tokaisi: "Et siis kerro totuutta!" Sitten hän kuitenkin myönsi: "Totta, me kaikki olemme herroja [signori - ja signore, rouvia] kodeissamme mutta ulkopuolella emme ole ketään.” Ehkäpä tässä on etnografisen asennoitumiseni oikeutus ja etnografisen kuvauksen mieli. Tutkimukseni kuvaa sitä, mitä kaikkea rouvuus - niin (muistettu) mennyt, (eletty) nykyinen kuin (kuviteltu) tulevaisuudessa häämöttäväkin - Rione Toianossa pitää sisällään ja ympärillään. Etnografinen ote tarjoaa mahdollisuuden sekä realismiin että toisin kuvittelemiseen. 


\section{VIITTEET}

1. Kiitän Laura Assmuthia ja Jukka Siikalaa artikkelin käsikirjoituksen kommentoinnista sekä kollegojani ja opiskelijoitani erilaisia kenttiä, töitä ja etnografisia orientaatioita koskeneista keskusteluista. Kenttätyötäni sen eri vaiheissa rahoitti Suomen Kulttuurirahasto.

2. Matka tutkimuksen metaforana myös yksinkertaistaa pitkän työn erilaisia vaiheita. Pozzuoli on pitänyt minua eri tavoin otteessaan jo yli kaksi vuosikymmentä. Kenttätyöni koostuu lukuisista vierailuista, erilaisista saapumisista ja lähdöistä.

3. Kenttätyöni ensimmäisessä vaiheessa talvella 1985-1986 kuuluin viiden sosiaaliantropologian opiskelijan ryhmään. Ryhmän muut jäsenet olivat Laura Assmuth, Kristiina Kangaspunta, Pia Mero ja Merja Rastas. Italian olimme valinneet samanaikaisesti helppona ja riittävän haastavana tutkimuskohteena, etelään päädyimme kuten valtaosa muistakin antropologeista. Pozzuolin löysimme kaupungin poikkeustilanteen seurauksena syntyneiden yhteyksien kautta. Vulkaanisen ilmiön seurauksena kaupunki oli "hätätilassa" eli keskusta oli lähes tyhjennetty, ja tilannetta selvittäneet Napolin yliopiston tutkijat kutsuivat paikalle myös ulkomaalaisia tutkijoita. Rione Toianoon pääseminen oli onnekas sattuma. Enemmistö lähiön asukkaista oli kotoisin Pozzuolin keskustan 1970-luvulla ja sittemmin 1980-luvun puolivälissä evakuoiduista kortteleista.

4. Olen pohtinut, missä määrin tämä vaikutelma johtuu omasta, lähes syyllisyydentuntoisesta suhtautumisestani. Tiettyä tukea varovaisuudelleni sain Thomas Belmonten (1989) Napolin köyhälistökorttelien kuvauksesta, varsinkin tutkimuksen epilogista, jossa hän kertoo Napoliin palattuaan tienneensä kirjassaan tehneensä petoksen, minkä todensi hänen mentoriperheensä suhtautuminen kirjaan. Se piilotettiin visusti kun Belmontelta oli ensin kysytty: "Onko siinä kirjassa siitäkin kun...?” Kesällä 1997 olin jännittyneenä vastaavassa tilanteessa. Annoin isäntäperheeni äidille tuliaisteni ohessa suomenkielisen (!) väitöskirjani. Vaatimattomista lahjoista käytiin tuttu keskustelu ('miksi ihmeessä olet tuhlannut rahaa, olet taas pahoittanut mieleni") mutta kirjaa hän ei kommentoinut vaan laittoi sen oitis pois. Toisaalta pikaisten tervehdyskäyntieni yhteydessä muissa perheissä kirjasta saatettiin keskustella, ja käänsin siitä osia italiaksi.

\section{TUTKIMUSAINEISTOT}

Artikkelissa olevat aineistoviittaukset perustuvat Anna-Maria Tapanisen Pozzuolissa, Etelä-Italiassa tekemään kenttätyöhön, joka koostui useista jaksoista vuodesta 1985 vuoteen 2001. Haastatteluaineistot, kenttäpäiväkirjat ja valokuvat ovat tekijän hallussa. 


\section{AnNa-Maria TAPANinen}

\section{KiRJALLISUUS}

AUGÉ, MARC 1997: Storie del presente. Per un'antropologia dei mondi contemporanei. Milano: Saggiatore.

BELMONTE, THOMAS 1989: The Broken Fountain. New York: Columbia University Press.

BOURDIEU, PIERRE 1990: The Logic of Practice. Cambridge: Polity Press.

CAMPBELL, JOHN 1992: Fieldwork among the Sarakatsani, 1954-55. - Piña-Cabral, Joao \& Campbell, John (eds.), Europe Observed. London: Macmillan.

CLIFFORD, JAMES 1986: Introduction: Partial Truths. - Clifford, James \& Marcus, George E. (eds.), Writing Culture: The Poetics and Politics of Anthropology. Berkeley: University of California Press.

CLIFFORD, JAMES \& MARCUS, GEORGE E. (eds.), 1986: Writing Culture: The Poetics and Politics of Ethnography. Berkeley: University of California Press.

COMAROFF, JEAN 1994: Contentious Subjects: Moral Being in the Modern World. - Suomen Antropologi 21(2).

COMAROFF, JOHN \& COMAROFF, JEAN 1992: Ethnography and the Historical Imagination. Boulder: Westview Press.

CRAPANZANO, VINCENT 1986: Hermes's Dilemma: The Masking of Subversion in Ethnographic Description. - Clifford, James \& Marcus, George E. (eds.), Writing Culture: The Poetics and Politics of Anthropology. Berkeley: University of California Press.

FABIAN, JOHANNES 1994: Ethnographic Objectivity Revisited: From Rigor to Vigor. - Megill, Alan (ed.), Retbinking Objectivity. Durhan: Duke University Press.

FARDON, RICHARD 1990: Localizing Strategies: The Regionalization of Ethnographic Accounts. - Fardon, Richard (ed.), Localizing Strategies: Regional Traditions in Ethnographic Writing. Edinburgh: Scottish Academic Press.

FAUBION, JAMES D. 2001: Currents in Cultural Fieldwork. - Atkinson, Paul \& Coffey, Amanda \& Delamond, Sara \& Lofland, John \& Lofland, Lyn (eds.), Handbook of Ethnography. London: Sage.

GEERTZ, CLIFFORD 1973: The Interpretation of Cultures. Selected Essays by Clifford Geert\%: New York: Basic Books.

- 1983: Local Knowledge: Further Essays in Interpretive Anthropology. New York: Basic Books.

HASTRUP, KIRSTEN 1986: Veracity and Visibility: The Problem of Authenticity in Anthropology. - Folk 28(1).

- 1995: A Passage to Anthropology: Between Experience and Theory. London: Routledge.

JENKINS, TIMOTHY1994: Fieldwork and the perception of everyday life. - MAN 29(2).

KNAUFT, BRUCE 1996: Genealogies for the Present in Cultural Anthropology. New York: Routledge.

LEDERMAN, RENA 1990: Pretexts for Ethnography: On Reading Fieldnotes. Sanjek, Roger (ed.), Fieldnotes: The Makings of Anthropology. Ithaca: Cornell University Press. 
MALINOWSKI, BRONISLAW 1961: Argonauts of the Western Pacific. New York: Dutton. [1922]

ORTNER, SHERRY B.1995: Resistance and Ethnographic Refusal. - Comparative Studies in Society and History 37(1).

OTTENBERG, SIMON 1990: Thirty Years of Fieldnotes: Changing Relationships to the Text. - Sanje, Roger (ed.), Fieldnotes: The Makings of Anthropology. Ithaca: Cornell University Press.

PITT-RIVERS, JULIAN 1954: The People of the Sierra. Chicago: Chicago University Press.

SIIKALA, JUKKA 1997: Kulttuurin käsite ja etnografian ongelma. - Viljanen, Anna Maria \& Lahti, Minna (toim.), Kaukaa haettua. Kirjoituksia antropologisesta kenttätyöstä. Helsinki: Suomen Antropologinen Seura.

SPENCER, JONATHAN 2001. Ethnography after Postmodernism. - Atkinson, Paul \& Coffey, Amanda \& Delamond, Sara \& Lofland, John \& Lofland Lyn (eds.), Handbook of Ethnography. Lontoo: Sage.

STOCKING, GEORGE 1992: The Ethnographer's Magic and Other Essays in the History of Anthropology. Wisconsin: University of Wisconsin Press.

STRATHERN, MARILYN 1991: Partial Connections. Lanham: Rowman \& Littlefield. TAPANINEN, ANNA-MARIA 1996: Kansan kodit ja kaupungin kadut. Etnografinen tutkimus eteläitalialaisesta kaupungista. Helsinki: Suomen Antropologinen Seura.

- 1997: Paljaat totuudet ja etnografiset illuusiot. - Viljanen, Anna Maria \& Lahti, Minna (toim.), Kaukaa baettua. Kirjoituksia antropologisesta kenttätyöstä. Helsinki: Suomen Antropologinen Seura.

THORNTON, ROBERT J. 1988: The Rhetoric of Ethnographic Holism. - Cultural Anthropology 3(3).

WHYTE, WILLIAM FOOTE 1996: On the Evolution of Street Corner Society. - Lareau, Annette \& Schultz, Jeffrey (eds.), Journeys through Ethnography: Realistic Accounts of Fieldwork. Boulder: Westview Press. [1955]

WOLCOTT, HARRY F. 1995: The Art of Fieldwork. Walnut Creek: AltaMira Press. — 1999. Ethnography: A Way of Seeing. Lanham: AltaMira Press.

Valtiotieteiden tohtori, antropologi Anna-Maria Tapaninen työskentelee tutkijana ja opettajana Helsingin yliopiston sosiologian laitoksessa. 